\title{
Cerebral Venous Thrombosis in COVID-19: A New York Metropolitan Cohort Study
}

\author{
(D). Al-Mufti, (D). Amuluru, (D) R. Sahni, (D). Bekelis, (D). Karimi, (D). Ogulnick, (D). Cooper, (D). Overby, (D). Nuoman, \\ (D) A. Tiwari, DK. Berekashvili, (D) N. Dangayach, (D). Liang, (D) Gupta, (D) P. Khandelwal, (D).F. Dominguez, (D). Sursal, \\ (D) H. Kamal, (D) K. Dakay, (D) B. Taylor, (D)E. Gulko, (D) M. El-Ghanem, (D) S.A. Mayer, and (D). Gandhi
}

\begin{abstract}
BACKGROUND AND PURPOSE: Severe Acute Respiratory Syndrome coronavirus 2 (SARS-CoV-2) infection is associated with hypercoagulability. We sought to evaluate the demographic and clinical characteristics of cerebral venous thrombosis among patients hospitalized for coronavirus disease 2019 (COVID-19) at 6 tertiary care centers in the New York City metropolitan area.
\end{abstract}

MATERIALS AND METHODS: We conducted a retrospective multicenter cohort study of 13,500 consecutive patients with COVID-19 who were hospitalized between March 1 and May 30, 2020.

RESULTS: Of 13,500 patients with COVID-19, twelve had imaging-proved cerebral venous thrombosis with an incidence of 8.8 per 10,000 during 3 months, which is considerably higher than the reported incidence of cerebral venous thrombosis in the general population of 5 per million annually. There was a male preponderance ( 8 men, 4 women) and an average age of 49 years ( $95 \% \mathrm{Cl}$, 36-62 years; range, 17-95 years). Only 1 patient (8\%) had a history of thromboembolic disease. Neurologic symptoms secondary to cerebral venous thrombosis occurred within 24 hours of the onset of the respiratory and constitutional symptoms in $58 \%$ of cases, and $75 \%$ had venous infarction, hemorrhage, or both on brain imaging. Management consisted of anticoagulation, endovascular thrombectomy, and surgical hematoma evacuation. The mortality rate was $25 \%$.

CONCLUSIONS: Early evidence suggests a higher-than-expected frequency of cerebral venous thrombosis among patients hospitalized for COVID-19. Cerebral venous thrombosis should be included in the differential diagnosis of neurologic syndromes associated with SARS-CoV-2 infection.

ABBREVIATIONS: COVID-19 = coronavirus disease 2019; CVST $=$ cerebral venous sinus thrombosis; CVT $=$ cerebral venous thrombosis; SARS-CoV- $2=$ Severe Acute Respiratory Syndrome coronavirus 2

C oronavirus disease 2019 (COVID-19) is predominantly an acute respiratory disease caused by a single-stranded RNA virus known as severe acute respiratory syndrome coronavirus 2

Received December 12, 2020; accepted after revision February 23, 2021.

From the Departments of Neurosurgery (F.A.-M., R.S., J.C., P.O., R.N., J.F.D., T.S., E.G., S.A.M., C.G.) and Neurology (F.A.-M., R.S., J.O., H.K., K.D., E.G., S.A.M., C.G.), Westchester Medical Center at New York Medical College, Valhalla, New York; Department of Neurosurgery (K. Bekelis), Catholic Health Services and Good Samaritan Hospital, West Islip, New York; Department of Neurosurgery (R.K.), Hackensack University Medical Center, Hackensack, New Jersey; Department of Neurosurgery (A.T., K. Berekashvili), New York University, New York, New York; Department of Neurosurgery (N.D., J.L.), Icahn School of Medicine at Mount Sinai, New York, New York; Department of Neurological Surgery (G.G., P.K., B.T.), Rutgers University, New Brunswick, New Jersey; Department of Neurology (M.E.-G.) University of Arizona-Tuscon, Tuscon, Arizona; and Department of Radiology (K.A.), Goodman Campbell Brain and Spine, Indianapolis, Indiana.

Please address correspondence to Fawaz Al-Mufti, MD, Westchester Medical Center at New York Medical College School of Medicine, 100 Woods Rd, Macy Pavilion 1331, Valhalla, NY 1059; e-mail: Fawaz.Al-Mufti@wmchealth.org

- Indicates open access to non-subscribers at www.ajnr.org

Indicates article with online supplemental data.

http://dx.doi.org/10.3174/ajnr.A7134
(SARS-CoV-2), which originated in Wuhan, China. ${ }^{1}$ The virus possesses a spike protein that binds to angiotensin-converting enzyme receptors, expressed on respiratory epithelium, facilitating entry into the host cell. ${ }^{2-4}$ Susceptibility of organ systems to this virus may depend on the extent of expression of angiotensin-converting enzyme receptors on cell surfaces. These receptors are expressed on endothelial cells, pericytes, macrophages, glial cells, and cardiac myocytes. ${ }^{2-4}$ Viral entry into these cells can lead to diverse manifestations such as acute respiratory distress syndrome, acute kidney injury, transaminitis, cardiac injury, and neurologic complications. $^{3-6}$

Neurologic symptoms include headache, confusion, hypogeusia, hyposmia, myalgias, and delirium, while neurologic complications include acute ischemic stroke, encephalitis, and Guillain-Barre syndrome. ${ }^{3,6-8}$ Postmortem data have revealed cerebral edema and partial neuronal degeneration in some patients as well. ${ }^{9}$

Early evidence suggests an increased risk of acute ischemic stroke in patients with COVID-19, which has been linked to a hypercoagulable state that can develop in some patients with 
COVID-19. ${ }^{10}$ It remains unknown whether infection with the SARS-CoV-2 virus can also lead to cerebral venous thrombosis (CVT).

\section{MATERIALS AND METHODS}

We conducted a retrospective multicenter cohort study of 13,500 consecutive patients with COVID-19 who were hospitalized between March 1 and May 30, 2020, in 6 academic, tertiary care facilities that are also designated as comprehensive stroke centers in the New York City metropolitan area. The number of hospital beds ranged from 500 to 1100 . The patients were identified by conducting a retrospective review of prospectively maintained stroke data bases in each of these collaborating centers. The goal of our study was to characterize the frequency and demographic and clinical characteristics of hospitalized patients with SARSCoV-2 who developed CVT. This study was approved by the individual enrolling hospitals' institutional review board centers.

\section{Clinical Management}

Clinical management of CVT conformed to the American Heart Association/American Stroke Association and Society of Neurointerventional Surgery guidelines. ${ }^{11,12}$ The diagnostic criteria and classification of COVID-19 severity was defined by the American Thoracic Society criteria. ${ }^{13}$

\section{Data Collection}

Comprehensive data on each patient were collected, including demographics, medical history, baseline clinical status, imaging results and treatment, and complications during hospitalization. Clinical data for COVID-19 diagnosis and management were retrieved from the medical records as well, which included demographic features, medical history, clinical symptoms, laboratory findings, lung CT findings on admission, treatment regimens, and clinical outcomes. Prior prothrombotic risk was defined as any history of a clinically significant thromboembolic event.

\section{Clinical and Radiologic Variables}

The diagnosis of the CVT was established by admission CT or MR venography. All included patients also underwent a noncontrast CT of the head. In patients with intracranial hemorrhages, hematoma volumes were measured using the $\mathrm{ABC} / 2$ technique modified for ellipsoid chronic subdural hematoma $(\mathrm{cSDH}) .{ }^{14}$ The diagnosis was confirmed following adjudication by a cerebrovascular specialist and a neuroradiologist.

\section{RESULTS}

During the study period, of 13,500 patients with COVID-19 admitted to 6 different New York metropolitan tertiary care centers, 12 patients $(8.8: 10,000)$ had imaging-proved CVT. The demographic and clinical characteristics of our patients are summarized in the Online Supplemental Data.

The mean age in our cohort was 48 years ( $95 \%$ CI, 36-62 years) (interquartile range, 31-63 years) with 25\% of patients younger than 25 years of age. Men accounted for $66 \%(8 / 12)$ of cases. $50 \%$ of the patients $(6 / 12)$ were White. Prior prothrombotic risk was identified in only $17 \%(2 / 12)$ of patients (breast cancer and deep vein thrombosis). However, traditional cardiovascular risk factors

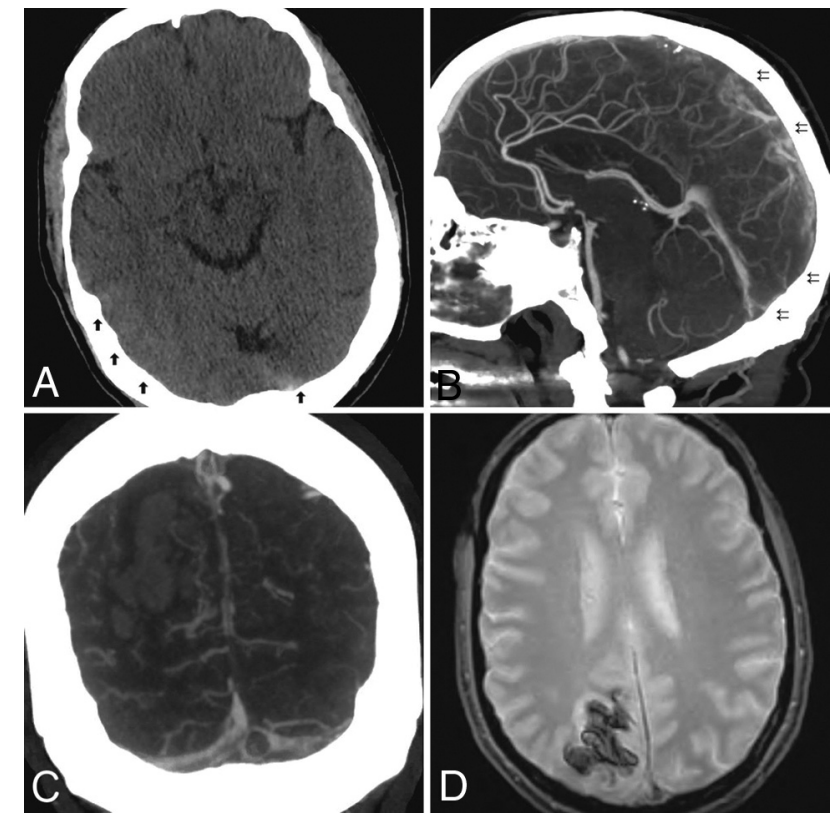

FIG 1. A, NCCT shows hyperdense thrombus in the region of the torcula and subtle cortical hyperdensity along the right temporo-occipital region (arrows). Sagittal $(B)$ and coronal MIP $(C)$ reformatted images of CTA show multiple filling defects along the posterior superior sagittal sinus (double arrows), torcula, and right transverse sinus. Note a parenchymal hematoma in the right occipital lobe. $D$, MR imaging of the brain; gradient recalled-echo sequence shows thrombus in the sagittal sinus and associated parenchymal hematoma.

(hypertension, hyperlipidemia, diabetes, smoking) were identified in $58 \%(7 / 12)$ of patients.

Neurologic symptoms secondary to CVT occurred within 24 hours of the onset of the respiratory and constitutional symptoms (fever, cough, dyspnea, myalgia, and fatigue) in $58 \%$ (7/12) of patients. Of the remaining patients, 25\% (3/12) developed CVT symptoms between 24 and 72 hours from symptom onset, and $16 \%(3 / 12)$ manifested CVT between 3 and 7 days from symptom onset.

Headache was the most common clinical neurologic symptom noted in $85 \%(10 / 12)$ of patients. Both seizures and hemiparesis occurred in $42 \%$ of patients. Cortical signs such as aphasia, neglect, or hemianopia were noted in only $25 \%$ of patients. Fever or cough was the most common symptom attributed to the COVID-19 infection and was noted in 75\% (9/12) of patients.

Neuroimaging demonstrated focal brain injury in $75 \%$ of patients. Isolated hemorrhage $(n=4)$, venous infarction $(n=2)$, or venous infarction with hemorrhagic changes $(n=3)$ was about equally represented. Vessel imaging identified dural venous sinus thrombosis in $83 \%(10 / 12)$ of patients and isolated cortical vein thrombosis in $16 \%(2 / 12)$ of patients. Multiple dural sinuses were involved in $41 \%(5 / 12)$ of patients (Fig 1$)$.

Anticoagulation was administered to $83 \%(10 / 12)$ of patients. Two patients were treated with endovascular thrombolysis (Fig 2). Hemicraniectomy was also performed in 2 patients. Of the 2 patients who did not receive treatment for their CVT, one patient died; and the second patient, who had a cortical vein as well as a nonocclusive superior sagittal sinus thrombosis, refused treatment.

AJNR Am J Neuroradiol 42:1196-1200 Jul 2021 www.ajnr.org 1197 


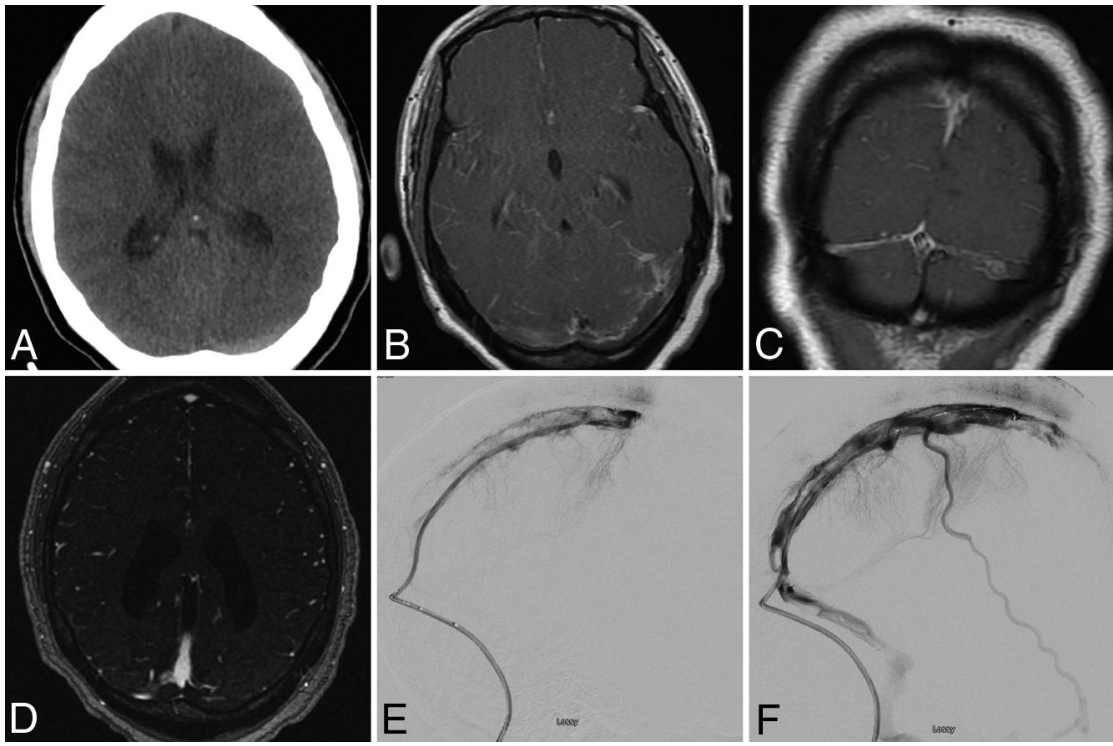

FIG 2. A, NCCT shows a subtle hyperdense thrombus in left transverse sinus. MR imaging of the brain: Tl postgadolinium images in axial $(B)$ and sagittal $(C)$ projections and MRV $(D)$ with gadolinium showing sinus thrombosis of the torcula with extension to the bilateral, left-greater-thanright, transverse sinuses. E, Endovascular microcatheter venogram shows progression of thrombus throughout superior sagittal sinus. F, A postinterventional venogram shows improved patency after mechanical thrombectomy.

Although all patients met the criteria for admission to the intensive care unit, mechanical ventilation was required in $41 \%$ of patients (5/12), and the median duration of ventilation was 15 days. One patient required a tracheostomy, while the remaining patients were successfully extubated. Acute renal failure was noted in $33 \%(4 / 12)$, acute liver failure occurred in $25 \%(3 / 12)$, and $8 \%(1 / 12)$ developed superimposed sepsis. One patient developed concomitant deep vein thrombosis. Hydroxychloroquine with or without azithromycin was administered to half $(6 / 12)$ of the patients. No patients received steroids or remdesivir. Three patients $(25 \%)$ were discharged home. Half $(6 / 12)$ of patients were transferred to a rehabilitation facility (5 to acute rehabilitation and 1 patient to subacute rehabilitation). The mortality rate in our cohort was $25 \%(3 / 12)$.

\section{DISCUSSION}

Our findings on CVT in the setting of COVID-19, pooled from 6 tertiary care centers in the New York metropolitan area, demonstrate the predominance of individuals younger than 25 years of age in $25 \%$ of cases, with a male preponderance. Only 1 patient in our cohort was African American, despite the fact that Black individuals are more severely affected by severe COVID-19. In terms of risk factors, traditional thrombogenic risk factors were identified in only 1 of 12 patients, and 7 of 12 had traditional cardiovascular risk factors. Most patients (10 of 12) presented with headache, and half presented with seizures or unilateral weakness. This presentation is in addition to the fever and cough attributed to COVID-19 infection in 9 of 12 patients, with 5 of 12 requiring mechanical ventilation. Neuroimaging was significant for brain injury, including hemorrhage, venous infarction, venous infarction with hemorrhagic changes, dural venous sinus thrombosis, and isolated cortical vein thrombosis in most (9 of 12) patients. Ten of 12 patients were treated with anticoagulation, 2 with endovascular thrombolysis, 2 with hemicraniectomy, and 6 with hydroxychloroquine with or without azithromycin. Of the 2 patients who did not receive treatment for their CVT, one died; the other patient, who had a cortical vein as well as a nonocclusive superior sagittal sinus thrombosis, refused treatment.

We collected our cases during the height of the COVID-19 pandemic (March through May 2020). During this 3-month period, CVT was diagnosed in 12 of 13,500 hospitalized patients with COVID-19, for a frequency of 0.088 per million. By contrast, the reported incidence of CVT in the general population is 5 per million annually. ${ }^{11}$ The higher-thanexpected rate of CVT among hospitalized patients with COVID-19, along with the well-established hypercoagulability that is known to occur with SARS-CoV-2 infection, supports a causal effect.

The literature demonstrates that $36 \%-59 \%$ of patients with COVID-19 have neurologic complications. ${ }^{1,2}$ Ischemic stroke incidence is estimated to be in the range of $5 \%$, with a recent study demonstrating an unusual presentation of young patients with COVID-19 with arterial stroke. ${ }^{2,5}$ By contrast, cerebral venous sinus thrombosis (CVST) associated with COVID-19 is an exceedingly rare occurrence, with only 57 reports available at the time this writing (Online Supplemental Data). ${ }^{15-43}$ The average age of these previously reported patients is 53.5 years (range, 2372 years), which is in agreement with our findings. Although we report a male preponderance, these 57 cases demonstrate an equal distribution of male and female patients. A direct comparison between our patients and those reported in the Online Supplemental Data is challenging in light of the substantial heterogeneity of demographic and clinical characteristics of patients with COVID-19 with CVST. Most previously reported patients had clinical CVST in a delayed fashion from initial symptoms attributable to COVID-19, whereas more than half of our patients presented with CVT concomitant with respiratory and constitutional symptoms. Because headache can be a common symptom of viral illnesses including COVID-19, diagnosis can often be elusive or delayed until symptoms worsen. ${ }^{7}$ Patients with either no or minimal systemic and respiratory symptoms may first come to medical attention when they present with seizures or other symptoms attributed to the venous sinus thrombosis and are ultimately found to have COVID-19 infection. ${ }^{8}$

While treatment guidelines for patients with COVID-19related strokes are emerging, it is unclear whether any intervention can prevent these outcomes. ${ }^{43}$ Although anticoagulation is 
being used prophylactically at many centers to prevent the thrombotic complications related to COVID-19, its benefit in stroke prevention remains to be seen. Two of our patients were on anticoagulation when their strokes were detected, and in one of those patients, the anticoagulation may have contributed to hemorrhagic conversion.

There have been several proposed mechanisms of neurologic manifestations following infection with coronaviruses. ${ }^{44}$ The virus may initially invade endothelial cells through angiotensinconverting enzyme receptors. ${ }^{45}$ The presence of viral elements within endothelial cells and an accumulation of inflammatory cells, with evidence of inflammatory cell death, have been demonstrated in patients with COVID-19. ${ }^{44}$ Inflammation of endothelial cells may cause cellular dysfunction, leading to either disruption of stable atherosclerotic plaque or circulatory changes in vascular beds, through a thrombogenic microvascular environment, manifesting as stroke, pulmonary embolism, or myocardial infarction. Critical SARS-CoV-2 infection is almost always accompanied by a significant proinflammatory response, which can activate the coagulation cascade through various pathways, leading to a profound prothrombotic state. This is consistent with 5 of 12 patients in our cohort having elevated D-dimer levels.

SARS-CoV-2 infection has also been linked to alternative and lectin complement cascade activation. ${ }^{46}$ These complement complexes can deposit on endothelial cells, leading to cellular damage, and can initiate a thrombotic microangiopathy. ${ }^{47}$ The presence of antiphospholipid antibodies and lupus antibodies has also been described in patients with COVID-19, though their clinical significance remains unknown. ${ }^{48}$

Several caveats and weaknesses of this study deserve mention. Complete screening for pre-existing hypercoagulable states was not performed in all patients. However, the temporal association of CVT with respiratory and constitutional symptoms of COVID-19 in more than half of our patients suggests a causal effect. It is possible that some patients with CVT due to COVID19 were not included in this series because their symptoms or signs were not properly diagnosed or charted. We were unable to compare baseline demographic and disease-related features between the CVT patient population and the main cohort of patients with COVID-19; this comparison might have allowed us to confirm male sex and identify other risk factors for CVT. Similarly, we also were unable to provide an estimate of the frequency of CVT among patients with COVID-19 who underwent brain imaging. Because all our patients were sick enough to be admitted to the hospital, multiple confounding factors could have contributed to our observed complications and outcomes. Additionally, because our sample of patients with confirmed CVT is limited to patients with COVID-19 who had neurologic issues, we are unable to assess the frequency of CVT in the overall COVID-19 cohort. It is also difficult to compare the incidence of CVT in the COVID-19 cohort with that of the general population due to differences in demographics between our cohort and the general population. Finally, the small number of included patients and restriction of our study population to the New York metropolitan area may limit the generalizability of our findings to other regions throughout the world. Larger analyses of this complication, such as a pooled meta-analysis, are warranted in the future, especially when more data become available.

\section{CONCLUSIONS}

SARS-CoV-2 has already infected millions of patients worldwide. Dreaded thrombotic complications, including CVST, have been reported in patients with SARS-CoV-2. As more reports of COVID-related CVST become available, it is hoped that our understanding of which patients are most at risk and the ideal treatment and prevention strategies can be elucidated.

Disclosures: Priyank Khandelwal—UNRELATED: Grants/Grants Pending: Feasibility of the Infinity Catheter for transradial neurology procedures; Payment for Lectures Including Service on Speakers Bureaus: American College of Cardiology meeting.

\section{REFERENCES}

1. Wang HY, Li XL, Yan ZR, et al. Potential neurological symptoms of COVID-19. Ther Adv Neurol Disord 2020;13:175628642091783 CrossRef Medline

2. Mao L, Jin H, Wang M, et al. Neurologic manifestations of hospitalized patients with coronavirus disease 2019 in Wuhan, China. JAMA Neurol 2020;77:683-90 CrossRef Medline

3. Zhou F, Yu T, Du R, et al. Clinical course and risk factors for mortality of adult inpatients with Covid-19 in Wuhan, China: a retrospective cohort study. Lancet 2020;395:1054-62 CrossRef Medline

4. Lu R, Zhao X, Li J, et al. Genomic characterisation and epidemiology of 2019 novel coronavirus: implications for virus origins and receptor binding. Lancet 2020;395:565-74 CrossRef Medline

5. Mankad K, Perry MD, Mirsky DM, et al. COVID-19: a primer for neuroradiologists. Neuroradiology 2020;62:647-48 CrossRef Medline

6. Baig AM, Khaleeq A, Ali U, et al. Evidence of the COVID-19 virus targeting the CNS: tissue distribution, host-virus interaction, and proposed neurotropic mechanisms. ACS Chem Neurosci 2020;11:995-98 CrossRef Medline

7. Ruan Q, Yang K, Wang W, et al. Clinical predictors of mortality due to COVID-19 based on an analysis of data of 150 patients from Wuhan, China. Intensive Care Med 2020;46:846-48 CrossRef Medline

8. Li YC, Bai WZ, Hashikawa T. The neuroinvasive potential of SARSCoV2 may play a role in the respiratory failure of COVID-19 patients. J Med Virol 2020;92:552-55 CrossRef Medline

9. Xu Z, Shi L, Wang Y, et al. Pathological findings of COVID-19 associated with acute respiratory distress syndrome. Lancet Respir Med 2020;8:420-22 CrossRef Medline

10. Oxley TJ, Mocco J, Majidi S, et al. Large-vessel stroke as a presenting feature of Covid-19 in the young. N Engl J Med 2020;382:660 CrossRef Medline

11. Saposnik G, Barinagarrementeria F, Brown RD Jr, et al. American Heart Association Stroke Council and the Council on Epidemiology and Prevention, Diagnosis and management of cerebral venous sinus thrombosis. a statement for healthcare professionals from the American Heart Association/American Stroke Association. Stroke 2011;42:1158-92 CrossRef Medline

12. Lee SK, Mokin M, Hetts SW, et al. Society of NeuroInterventional Surgery. Current endovascular strategies for cerebral venous thrombosis: report of the SNIS Standards and Guidelines Committee. J Neurointerv Surg 2018;10:803-10 CrossRef Medline

13. Jamil S, Mark N, Carlos G, et al. Diagnosis and management of COVID-19 disease. Am J Respir Crit Care Med 2020;201:P19-20 CrossRef Medline

14. Kothari RU, Brott T, Broderick JP, et al. The ABCs of measuring intracerebral hemorrhage volumes. Stroke 1996;27:1304-05 CrossRef Medline 
15. Dahl Cruz F, Guevara Dalrymple N, López Hernández N. Cerebral venous thrombosis and SARS-CoV-2 infection [in Spanish]. Rev Neurol 2020;70:391 CrossRef Medline

16. Hughes $\mathrm{C}$, Nichols T, Pike M, et al. Cerebral venous sinus thrombosis as a presentation of COVID-19. Eur J Case Rep Intern Med 2020;7:001691CrossRef Medline

17. Garaci F, Di Giuliano F, Picchi E, et al. Venous cerebral thrombosis in COVID-19 patient. J Neurol Sci 2020;414:116871 CrossRef Medline

18. Poillon G, Obadia M, Perrin M, et al. Cerebral venous thrombosis associated with Covid-19 infection: causality or coincidence? J Neuroradiol 2021;48:121-24 CrossRef Medline

19. Hemasian H, Ansari B. First case of Covid-19 presented with cerebral venous thrombosis: a rare and dreaded case. Rev Neurol (Paris) 2020;176:521-23 CrossRef Medline

20. Klein D, Libman R, Kirsch C, et al. Cerebral venous thrombosis: a typical presentation of COVID-19 in the young. J Stroke Cerebrovasc Dis 2020;29:104989 CrossRef Medline

21. Cavalcanti DD, Raz E, Shapiro M, et al. Cerebral venous thrombosis associated with COVID-19. AJNR Am J Neuroradiol 2020;41:1-7 CrossRef Medline

22. Li Y, Li M, Wang M, et al. Acute cerebrovascular disease following COVID-19: a single center retrospective, observational study. Stroke Vasc Neurol 2020;5:279-84 CrossRef Medline

23. Baudar C, Duprez T, Kassab A, et al. COVID-19 as triggering co-factor for cortical cerebral venous thrombosis? J Neuroradiol 2021;48:65-67 CrossRef Medline

24. Bolaji P, Kukoyi B, Ahmad N, et al. Extensive cerebral venous sinus thrombosis: a potential complication in a patient with COVID-19 disease. BMJ Case Rep 2020;13:e236820 CrossRef Medline

25. Chougar L, Mathon B, Weiss N, et al. Atypical deep cerebral vein thrombosis with hemorrhagic venous infarction in a patient positive for COVID-19. AJNR Am J Neuroradiol 2020;41:1377-79 CrossRef Medline

26. Chow LC, Chew LP, Leong TS, et al. Thrombosis and bleeding as presentation of COVID-19 infection with polycythemia vera: a case report. SN Compr Clin Med 2020 Oct 4. [Epub ahead of print] CrossRef Medline

27. Haroon KH, Muhammad A, Hussain S, et al. COVID-19 related cerebrovascular thromboembolic complications in three young patients. Case Rep Neurol 2020;12:321-28 CrossRef Medline

28. Hoelscher C, Sweid A, Ghosh R, et al. Cerebral deep venous thrombosis and COVID-19: case report. J Neurosurg 2020 Sep 4. [Epub ahead of print] CrossRef Medline

29. Kananeh MF, Thomas T, Sharma K, et al. Arterial and venous strokes in the setting of COVID-19. J Clin Neurosci 2020;79:60-66 CrossRef Medline

30. Keaney K, Mumtaz T. Cerebral venous thrombosis in patients with severe COVID-19 infection in intensive care. Br J Hosp Med (Lond) 2020;81:1-4 CrossRef Medline

31. Koh JS, De Silva DA, Quek AM, et al. Neurology of COVID-19 in Singapore. J Neurol Sci 2020;418:117118 CrossRef Medline

32. Malentacchi M, Gned D, Angelino V, et al. Concomitant brain arterial and venous thrombosis in a COVID-19 patient. Eur J Neurol 2020;27:e38-39 CrossRef Medline
33. Mowla A, Shakibajahromi B, Shahjouei S, et al. Cerebral venous sinus thrombosis associated with SARS-CoV-2; a multinational case series. J Neurol Sci 2020;419:117183 CrossRef Medline

34. Rifino N, Censori B, Agazzi E, et al. Neurologic manifestations in $\mathbf{1 7 6 0}$ COVID-19 patients admitted to Papa Giovanni XXIII Hospital, Bergamo, Italy. J Neurol 2020 Oct 7. [Epub ahead of print] CrossRef Medline

35. Rouyer O, Pierre-Paul IN, Balde A, et al. High prevalence of deep venous thrombosis in non-severe COVID-19 patients hospitalized for a neurovascular disease. Cerebrovasc Dis Extra 2020 Dec 7. [Epub ahead of print] CrossRef Medline

36. Roy-Gash F, Marine DM, Jean-Michel D, et al. COVID-19-associated acute cerebral venous thrombosis: clinical, CT, MRI and EEG features. Crit Care 2020;24:419 CrossRef Medline

37. Shahjouei S, Naderi S, Li J, et al. Risk of stroke in hospitalized SARS-CoV-2 infected patients: a multinational study. EBioMedicine 2020;59:10293 CrossRef Medline

38. Siegler JE, Cardona P, Arenillas JF, et al. Cerebrovascular events and outcomes in hospitalized patients with COVID-19: the SVIN COVID-19 Multinational Registry. Int J Stroke 2020 Sep 30. [Epub ahead of print] CrossRef Medline

39. Sugiyama $Y$, Tsuchiya $T$, Tanaka $R$, et al. Cerebral venous thrombosis in COVID-19-associated coagulopathy: a case report. J Clin Neurosci 2020;79:30-02 CrossRef Medline

40. Thompson A, Morgan C, Smith P, et al. Cerebral venous sinus thrombosis associated with COVID-19. Pract Neurol 2020 Oct 8. [Epub ahead of print] CrossRef Medline

41. Trimaille A, Curtiaud A, Marchandot B, et al. Venous thromboembolism in non-critically ill patients with COVID-19 infection. Thromb Res 2020;193:166-69 CrossRef Medline

42. Tu TM, Goh C, Tan YK, et al. Cerebral venous thrombosis in patients with COVID-19 infection: a case series and systematic review. J Stroke Cerebrovasc Dis 2020;29:105379 CrossRef Medline

43. Qureshi AI, Abd-Allah F, Alsenani F, et al. Management of acute ischemic stroke in patients with COVID-19 infection: report of an international panel. Int J Stroke 2020;15:540-54 CrossRef Medline

44. Wu Y, Xu X, Chen Z, et al. Nervous system involvement after infection with COVID-19 and other coronaviruses. Brain Behav Immun 2020;87:18-22 CrossRef Medline

45. Chen L, Li X, Chen M, et al. The ACE2 expression in human heart indicates new potential mechanism of heart injury among patients infected with SARS-CoV-2. Cardiovasc Res 2020;116:1097-1100 CrossRef Medline

46. Magro C, Mulvey JJ, Berlin D, et al. Complement associated microvascular injury and thrombosis in the pathogenesis of severe COVID-19 infection: a report of five cases. Transl Res 2020;220:113 CrossRef Medline

47. Noris M, Galbusera M, Gastoldi S, et al. Dynamics of complement activation in aHUS and how to monitor eculizumab therapy. Blood 2014;124:1715-26 CrossRef Medline

48. Zhang Y, Xiao M, Zhang S, et al. Coagulopathy and antiphospholipid antibodies in patients with Covid-19. N Engl J Med 2020;382: e38 CrossRef Medline 